\title{
STRATEGI PENGEMBANGAN WISATA SYARIAH DI SUMATERA BARAT : ANALISIS SWOT (Strength, Weakness, Opportunity, Threath)
}

\author{
Rimet* \\ *Fakultas Ekonomi dan Ilmu Sosial, \\ Universitas Islam Negeri Sultan Syarif Kasim Riau \\ Jl. HR. Soebrantas Panam KM 15 No.155 tampan Pekanbaru, 28293 \\ e-mail : rimet@uin-suska.ac.id
}

\begin{abstract}
Abstrak: Penelitian ini bertujuan untuk mengetahui strategi pengembangan wisata syariah di Sumatera Barat dengan menggunakan analisis SWOT. Lokasi penelitian adalah di Sumatera Barat dan objek penelitian ini adalah pemerintah daerah Sumatera Barat yaitu Dinas Pariwisata Provinsi Sumatera Barat. Analisis data menggunakan analisis model SWOT. Berdasarkan hasil penelitian diketahui bahwa stretegi pengembangan wisata syariah di Sumatera Barat adalah menjadikan pariwisata sebagai sektor unggulan, diimplementasikan melalui suatu Gerakan terpadu pengembangan kepariwisataan, Rapat-Rapat Koordinasi dengan Pemerintah Provinsi, Kabupaten/Kota dan Stakeholder terkait, kesepakatan Pemerintah Provinsi, Kabupaten/Kota menjadikan Sumatera Barat sebagai Destinasi Wista Halal, terpilihnya Sumbar sebagai Destinasi Halal Terbaik Nasional, terpilihnya Sumbar sebagai Destinasi Kuliner Halal Terbaik Nasional, terpilihnya Sumbar sebagai World's Best Halal Destination, terpilihnya Sumbar sebagai World's Best Halal Culinary Destination, Sosialisasi Wisata Halal bagi Stackholder Pariwisata, memberikan subsidi untuk pengurusan Sertifikasi Halal untuk industri (rumah makan/restoran), menyusun Ranperda Pariwisata Halal.
\end{abstract}

Kata Kunci : Wisata Syariah, Halal, Analisis SWOT. 


\section{PENDAHULUAN}

Seiring dengan perkembangan industri periwisata, saat ini muncul istilah pariwisata syariah. Pada awalnya konsep syariah umumnya di gunakan pada dunia perbankan. Namun dunia pariwisata tidak mau ketinggalan. Sebagai negara yang berpenduduk muslim terbanyak di dunia, Indonesia memiliki peluang yang besar untuk menjadi destinasi utama pariwisata syariah dunia. Maka untuk mewujudkan hal tersebut, Kementerian Pariwisata dan Ekonomi Kreatif (Kemenparekraf) bekerjasama dengan Majelis Ulama Indonesia mengadakan Grand Launching Pariwisata Syariah pada tahun 2013.

Kementerian Pariwisata dan Ekonomi Kreatif menetapkan sembilan tujuan wisata yang memiliki potensi untuk dipromosikan sebagai kawasan wisata syariah di Indonesia. Sembilan daerah itu adalah Sumatera Barat, Riau, Lampung, Banten, Jakarta, Jawa Barat, Jawa Timur, Makassar, dan Lombok. Hal ini disebabkan karena kawasan wisata syariah tersebut memiliki latar sosial budaya yang menjunjung tinggi nilai-nilai Islam yang didukung keindahan alamnya (Asdhiana, 2014).

Prinsip yang digunakan dalam wisata syariah adalah untuk memastikan keamanan untuk konsumen dengan menekankan nilai kejujuran, integritas, dan menghormati budaya lokal. Ada lima komponen yang dimasukkan dalam wisata syariah oleh Kemamenparekraf dan MUI yaitu sektor kuliner, fashion muslim, perhotelan dan akomodasi, kosmetik dan spa, serta haji umrah. Jadi wisata syariah saat ini tidak hanya pada peninggalan sejarah Islam, ziarah kubur dan sejenisnya saja. Hal ini merupakan potensi besar yang dimiliki Indonesia yang hasil digarap secara maksimal.

Menurut data Global Muslim Travel Index (GMTI) tahun 2016, Indonesia merupakan salah satu negara anggota OKI (Organisasi Konferensi Islam) yang masuk sepuluh besar daerah tujuan wisata muslim dunia (diurutan ke empat) seperti terlihat pada grafik di bawah ini :

\section{Gambar 1. Destinasi Wisata Muslim Dunia}

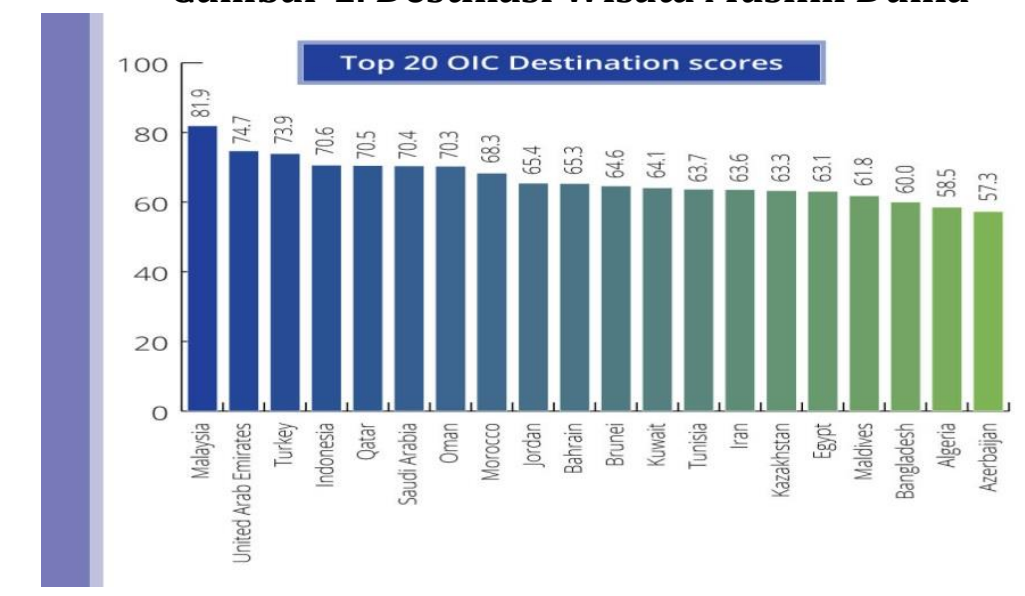

Sumber : GMT, 2016 
Wisata Syariah sesungguhnya bukanlah wisata eksklusif yang hanya diperuntukkan untuk kelompok wisatawan tertentu. Sehingga wisatawan non muslim juga dapat menikmati keindahan, pelayanan, serta segala macam daya tarik wisata yang beretika Syariah (Gilang, 2015). Hal ini disebabkan karena tujuan diadakannya pengembangan wisata syariah adalah untuk menarik wisatawan muslim maupun non-muslim, dan wisatawan dalam maupun luar negeri serta untuk mendorong tumbuh kembangnya bisnis syariah di lingkungan pariwisata Indonesia. Wisata Syariah memiliki produk dan jasa wisata yang serupa dengan konsep wisata secara konvensional hanya perbedaannya semua pendekatan dan kebijakan yang diterapkan mengacu kepada nilai-nilai syariah Islam.

Provinsi Sumatera Barat sebagai salah satu provinsi yang dikembangkan sebagai destinasi wisata syariah. Hal ini tentunya dinilai dari kesiapan Sumatera Barat dari sisi infrastruktur maupun masyarakat secara keseluruhan juga meliputi dunia usaha serta pemerintah daerah yang memberikan dukungan penuh dalam pengembangannya.

Keragaman masyarakat Sumatera Barat juga tentunya menjadi peluang besar sekaligus tantangan dalam mengembangkan pariwisata syariah ini. Selain itu, Sumatera Barat juga memiliki destinasi wisata syariah atau objek-objek wisata menarik untuk dikunjungi. Didukung dengan transportasi yang memadai, objek-objek wisata tersebut sangat mudah dijangkau.

Sumatera Barat memiliki beberapa penghargaan yang dapat menjadi indikator keberhasilan Sumatera Barat dalam mempersiapkan destinasi wisata syaraiah. Pada tahun 2016 dalam ajang World Halal Tourism Award (WHTA) yang diadakan di Abu Dhabi Uni Emirat Arab, Sumatera Barat mendapatkan tiga gelar sekaligus yaitu World's Best Halal Tour
Operator melalui Ero Tour, World's Best Halal Destination, dan World's Best Halal Culinary Destination. Keberhasilan Sumatera Barat dalam World Halal Tourism Award WHTA 2016 ini merupakan langkah yang baik dalam pengembangan wisata halal di Sumatera Barat.

Oleh karena itu untuk dapat mewujudkan Sumatera Barat sebagai salah satu destinasi wisata syariah adalah perlunya dukungan dari masyarakat terhadap pengembangan kepariwisataan di Sumatera Barat. Kemudian bagi pemerintah daerah dan pelaku usaha jasa pariwisata harus dapat merumuskan strategi yang paling tepat untuk dapat mengembangkan wisata syariah di Sumatera Barat.

Berdasarkan uraian diatas, maka penulis akan meneliti strategi pengembangan pasar wisata syariah di Sumatera Barat. Dalam rangka menghadapi persaingan di bidang pariwisata, maka penerapan strategi yang tepat untuk wisata syariah sangat penting untuk diketahui dan diterapkan.

Adapun permasalahan yang dikemukakan dalam penelitian ini adalah bagaimana strategi pengembangan wisata syariah di Sumatera Barat dengan menggunakan analisis SWOT?. Tujuan penelitian adalah untuk mengetahui strategi pengembangan wisata syariah di Sumatera Barat dengan menggunakan analisis SWOT.

\section{TINJAUAN PUSTAKA Wisata Syariah}

Pariwisata syariah adalah kegiatan yang didukung oleh berbagai fasilitas serta layanan yang disediakan masyarakat, pengusaha, pemerintah, dan pemerintah daerah yang memenuhi ketentuan syariah (Kemenpar, 2012). Menurut Sofyan (2012), definisi wisata syariah lebih luas dari wisata religi yaitu wisata yang didasarkan pada nilai-nilai syariah Islam. 
Pariwisata syariah dimanfaatkan oleh banyak orang karena karakteristik produk dan jasanya yang bersifat universal. Produk dan jasa wisata, objek wisata, dan tujuan wisata dalam pariwisata syariah adalah sama dengan produk, jasa, objek dan tujuan pariwisata pada umumnya selama tidak bertentangan dengan nilai-nilai dan etika syariah.

Konsep syariah yang tidak bertentangan dengan nilai-nilai dan etika syariah berhubungan dengan konsep halal dan haram di dalam Islam. Halal diartikan dibenarkan, sedangkan haram diartikan dilarang. Konsep halal dapat dipandang dari dua perspektif yaitu perspektif agama dan perspektif industri. Yang dimaksud dengan perspektif agama, yaitu sebagai hukum makanan apa saja yang boleh dikonsumsi oleh konsumen muslim sesuai keyakinannya. Ini membawa konsuekensi adanya perlindungan konsumen. Sedangkan dari perspektif industri. Bagi produsen pangan, konsep halal ini dapat diartikan sebagai suatu peluang bisnis. Bagi industri pangan yang target konsumennya sebagian besar muslim, diperlukan adanya jaminan kehalalan produk akan meningkatkan nilainya yang berupa intangible value (Hamzah dan Yudiana, 2015).

Kriteria umum pariwisata syariah ialah (Sofyan, 2012):

1. Memiliki orientasi kepada kemaslahatan umum.

2. Memiliki orientasi pencerahan, penyegaran, dan ketenangan.

3. Menghindari kemusyrikan dan khurafat.

4. Bebas dari maksiat.

5. Menjaga keamanan dan kenyamanan.

6. Menjaga kelestarian lingkungan.

7. Menghormati nilai-nilai sosial budaya dan kearifan lokal.

Istilah wisata halal dalam literatur

pada umumnya disamakan dengan beberapa istilah seperti Islamic tourism, syari'ah tourism, halal travel, halal friendly tourism destination, Muslimfriendly travel destinations, halal lifestyle, dan lain-lain. Dari sisi industri, wisata syariah merupakan suatu produk pelengkap dan tidak menghilangkan jenis pariwisata konvensional. Sebagai cara baru untuk mengembangkan pariwisata Indonesia yang menjunjung tinggi budaya dan nilai-nilai Islami tanpa menghilangkan keunikan dan orisinalitas daerah.

Wisata religi yang dimaksudkan bisa berarti pula wisata ziarah. Secara etimologi, ziarah dapat berarti kunjungan, baik kepada orang yang masih hidup maupun yang sudah meninggal, namun dalam aktivitas pemahaman masyarakat kunjungan kepada orang yang telah meninggal melalui kuburannya. Kegiatannya pun lazim disebut dengan ziarah kubur.

Dalam Islam, ziarah kubur dianggap sebagai perbuatan sunah. Praktik ziarah sebenarnya telah ada sebelum Islam, namun dilebih-lebihkan sehingga Rasulullah sempat melarangnya. Tradisi inipun dihidupkan kembali bahkan dianjurkan untuk mengingat kematian. Praktik ziarah sebenarnya telah ada sebelum Islam, namun overloud sehingga Rasulullah SAW pernah melarangnya. Tradisi inipun dihidupkan kembali bahkan dianjurkan untuk mengingat kematian.

Barber (1993) mengartikan "pilgrimage as a journey resulting from religious causes, externally to a holy site, and internally for spiritual purposes and internal understanding" (dalam Galzacorta \& Omil, 2016).

Pengertian wisata religi dikembangkan pula sebagai semua upaya pemasaran dan pengembangan produk yang diarahkan pada umat Islam, meskipun tidak terkait motivasi agama (Henderson, 2010), atau upaya yang menekankan pentingnya turis Muslim dan non-Muslim sebagai pasar baru dan tujuan untuk pariwisata. Dengan kata lain, 
Islamic tourism untuk mempromosikan pariwisata di kalangan umat Islam, mengembangkan tujuan wisata baru, dan memperkuat kerjasama antar organisasi dan antar-pemerintah di Dunia Islam.

Zamani Farahani and Anderson (2009) menegaskan bahwa "Islamic tourism can be defined as traveling activities of Muslims when moving from one place to another or when residing at one place outside their place of normal residence for a period less than one year and to engage in activities with Islamic motivations. It should be noted that Islamic activities must be in accordance with generally accepted principles of Islam; i.e. halal".

Jadi, pariwisata Islam dapat didefinisikan sebagai kegiatan perjalanan Muslim ketika bergerak dari satu tempat ke tempat lain atau ketika berada di satu tempat di luar tempat tinggal mereka yang normal untuk jangka waktu kurang dari satu tahun dan untuk terlibat dalam kegiatan dengan motivasi Islam. Perlu dicatat bahwa kegiatan wisata dalam Islam harus sesuai dengan prinsip-prinsip Islam yang berlaku umum, yaitu halal.

Wisata religi menunjukkan aktivitas perjalanan dengan motivasi atau tujuan keagamaan yang dilakukan oleh umat beragama (Muslim, Kristen, Hindu, Budha) yang biasanya dengan mengunjungi tempat-tempat suci agama atau tokoh agama. Pengertian tersebut berlaku juga untuk makna ziarah sebagai bagian dari aktivitas wisata. Karena itu, wisata religi sebagai suatu aktivitas ekonomi lebih tepat digunakan istilah wisata syari'ah jika yang melakukan aktivitas perjalanan adalah seorang Muslim.

Sofyan (2012) menegaskan bahwa defenisi wisata syariah lebih luas dari wisata religi yaitu wisata yang didasarkan pada nilai-nilai syariah Islam. Seperti yang dianjurkan oleh World Tourism Organization (WTO), konsumen wisata syariah bukan hanya umat Muslim tetapi juga non Muslim yang ingin menikmati kearifan lokal. Adapun kriteria umum pariwisata syariah ialah; pertama, memiliki orientasi kepada kemaslahatan umum. Kedua, memiliki orientasi pencerahan, penyegaran, dan ketenangan. Ketiga, menghindari kemusyrikan dan khurafat. Keempat, bebas dari maksiat. Kelima, menjaga keamanan dan kenyamanan. Keenam, menjaga kelestarian lingkungan. Ketujuh, menghormati nilai-nilai sosial budaya dan kearifan lokal.

Menurut Salama (2013), pada tahun 2011 belanja para wisatawan muslim di berbagai tujuan wisata di seluruh Negara diperkirakan mencapai USD 126 miliar dan jumlah ini diharapkan naik hingga menjadi USD 192 miliar pada tahun 2020. Oleh karena itu, sejumlah negara berinisiatif untuk menarik para wisatawan muslim agar berkunjung ke negaranya dengan mempersiapkan hotel berbasis syariah, dan menyebarkan brosur-brosur kepariwisataan dengan konsep berbasis syariah.

Segmen pasar produk dan jasa berbasis syariah bukan hanya untuk kaum muslimin, namun juga non muslim. Hal ini karena konsumsi produk dan jasa berbasis syariah berefek baik, sehat dan mengangkat gaya hidup (Ramli, 2011). Namun para wisatawan muslim tidak bisa diperlakukan dengan cara yang sama seperti wisatawan non muslim. Perbedaan yang cukup mendasar terletak pada tidak adanya perjudian, makanan mengandung babi, tidak adanya minuman beralkohol dan aktifitas-aktifitas terkait dengan pesta-pesta. Sebaliknya, kunjungan ke masjid-masjid dan situssitus Islami lainnya dapat dimasukkan ke dalam daftar tempat-tempat yang akan dikunjungi.

Produk-produk wisata berbasis syariah dapat mencakup kunjungan aktivitas seperti shopping, travelling, taman hiburan, kota-kota yang sangat padat, warisan budaya Islami, hutan hujan, ekowisata lainnya, hotel dan resort berbasis syariah yang tidak menawarkan 
minuman beralkohol, makanan yang mengandung babi dan segala produk turunannya, tempat dan jadwal sholat, tanda arah kiblat di kamar, kolam renang dan spa serta fasilitas lainnya yang memisahkan konsumen perempuan dan laki-laki, dan lain-lain, penerbangan berbasis syariah yang tidak menawarkan alcohol dan babi sepanjang penerbangan.

Dengan demikian, wisata berbasis syariah telah menciptakan altivitas ekonomi hulu-hilir yang berlandaskan pada prinsip-prinsip berbasis syariah yang diyakini akan memberi sumbangan pendapatan signifikan, baik kepada ekonomi dan perilaku masyarakat sekitar maupun negara.

Di era modern sekarang ini, wisata Islami harus didukung dengan kesiapan website, database kepariwisataan (segmen, lokasi, atraksi dan fasilitas fisik dan infrastruktur), jasa / layanan yang berkualitas tinggi dan portal untuk pemesanan transportasi / online.

Terdapat dua lembaga yang telah menjalin kerjasama untuk mewujudkan wisata syariah di Indonesia, yaitu MUI dan Kemenparekraf. MUI akan mengambil peran dalam proses sertifikasi produkproduk syariah, bahkan hingga pemandu wisata syariah akan disertifikasi. Artinya, MUI bertindak untuk menyiapkan bagaimana standarisasi syariah, sebagai pengawas terkait produk-produk wisata syariah, dan bertindak menjadi konsultan, pendampingan, pembinaan manajemen aspek kesyariahan, operator pariwisata syariah, juga memastikan syariahnya Biro Perjalanan, Pemandu Wisata, makanan berbasis syariah, serta restoran berbasis syariah. Semuanya kemudian dikemas dan dipromosikan oleh Kemenparekraf yang merupakan lembaga promosi wisata syariah.

Beberapa prinsip pengembangan wisata berbasis syariah mencakup :

1. Pengembangan fasilitas wisata berbasis syariah dalam skala besar atau kecil beserta pelayanan di luar dan di dalam atau dekat lokasi wisata.

2. Fasilitas dan pelayanan berbasis syariah tersebut dimiliki dan dikerjakan oleh masyarakat setempat, yang dilakukan dengan bekerja sama atau dilakukan secara individual oleh yang memiliki.

3. Pengembangan wisata berbasis syariah didasarkan pada salah satu "sifat" budaya tradisional yang lekat pada suatu lingkungan religious atau "sifat" atraksi berbasis syariah yang dekat dengan alam dimana pengembangan lingkungan sebagai pusat pelayanan berbasis syariah bagi wisatawan yang mengunjungi kedua atraksi tersebut.

\section{Strategi Pengembangan Pariwisata}

Menurut Joyosuharto (1995) pengembangan pariwisata memiliki tiga fungsi yaitu :

1. Menggalakkan ekonomi

2. Memelihara kepribadian bangsa dan kelestarian fungsi dan mutu lingkungan hidup

3. Memupuk rasa cinta tanah air dan bangsa

Sebuah destinasi dapat dikatakan akan melakukan pengembangan wisata jika sebelumnya sudah ada aktivitas wisata. Untuk dapat meningkatkan potensi pariwisatanya, yang perlu dilakukan adalah merencanakan pengembangan wisata agar dapat lebih baik dari sebelumnya. Tiga prinsip utama dalam sustainability development (McIntyre, 1993):

1. Ecological Sustainability, yakni memastikan bahwa pengembangan yang dilakukan sesuai dengan proses ekologi, biologi, dan keragaman sumber daya ekologi yang ada.

2. Social and Cultural Sustainability, yaitu memastikan bahwa pengembangan yang dilakukan memberi dampak positif bagi 
kehidupan masyarakat sekitar dan sesuai dengan kebudayaan serta nilai-nilai yang berlaku pada masyarakat tersebut.

3. Economic Sustainability, yaitu memastikan bahwa pengembangan yang dilakukan efisien secara ekonomi dan bahwa sumber daya yang digunakan dapat bertahan bagi kebutuhan di masa mendatang. Sementara itu dilain hal, sektor pariwisata terdiri atas beberapa komponen yang berbeda yang harus benar-benar dimengerti dan direncanakan dan dikembangkan secara terintegrasi dalam masyarakat. Segalanya untuk kenyamanan perencanaan pariwisata dalam masyarakat itu sendiri.

Menurut Kementerian Pariwisata dan Ekonomi kreatif dan BPH DSN-MUI pariwisata Syari'ah mempunyai kriteria umum sebagai berikut :

1. Berorientasi pada kemaslahatan umum.

2. Berorientasi pada pencerahan penyegaran dan ketenangan.

3. Menghindari kemusyrikan

4. Menghindari maksiat seperti zina pornografi pornoaksi minuman keras narkoba dan judi.

5. Menjaga perilaku etika nilai luhur kemanusiaan seperti menghindari perilaku hedonis dan asusila.

6. Menjaga amanah keamanan dan kenyamanan.

7. Bersifat universal dan inklusif.

8. Menjaga kelestarian lingkungan.

9. Menghormati nilai-nilai socialbudaya dan kearifan lokal

\section{ANALISIS SWOT}

Menurut Freddy Rangkuti (2009) analisis SWOT adalah identifikasi berbagai faktor secara sistematis untuk merumuskan strategi perusahaan. Analisis ini didasarkan pada logika yang dapat memaksimalkan kekuatan (Strengths) dan peluang (Opportunities), namun secara bersamaan dapat meminimalkan kelemahan (Weaknesses) dan ancaman (Threats). Proses pengambilan keputusan strategis selalu berkaitan dengan pengembangan misi, tujuan, strategi, dan kebijakan perusahaan.

Menurut Kotler (2009) analisis SWOT (Strenghts, Weakness, Opportunity, Threaths) merupakan cara untuk mengamati lingkungan pemasaran eksternal dan internal.

Analisis SWOT terdiri dari empat faktor, yaitu:

1. Strengths (kekuatan)

Merupakan kondisi kekuatan yang terdapat dalam organisasi, proyek atau konsep bisnis yang ada. Kekuatan yang dianalisis merupakan faktor yang terdapat dalam tubuh organisasi, proyek atau konsep bisnis itu sendiri

2. Weakness (kelemahan)

Merupakan kondisi kelemahan yang terdapat dalam organisasi, proyek atau konsep bisnis yang ada. Kelemahan yang dianalisis merupakan faktor yang terdapat dalam tubuh organisasi, proyek atau konsep bisnis itu sendiri.

3. Opportunities (peluang)

Merupakan kondisi peluang berkembang di masa datang yang terjadi. Kondisi yang terjadi merupakan peluang dari luar organisasi, proyek atau konsep bisnis itu sendiri. misalnya kompetitor, kebijakan pemerintah, kondisi lingkungan sekitar.

4. Threats (ancaman)

Merupakan kondisi yang mengancam dari luar. Ancaman ini dapat mengganggu organisasi, proyek atau konsep bisnis itu sendiri

Pengembangan wisata halal penting karena manfaatnya tidak hanya dapat dirasakan oleh wisatawan Muslim. Wisata halal bersifat terbuka untuk semua orang. Kemenparekraf akan 
menggerakkan wisata halal di hotel, restoran, serta spa. Diharapkan wisata halal dapat menjadikan Indonesia sebagai destinasi yang ramah untuk wisatawan Muslim dan memerlukan standarisasi. Ciri wisata halal antara lain ada paket-paket wisata halal yang meliputi destinasi ramah wisatawan Muslim, serta hotel, restoran, dan spa yang halal (Kemenparekraf, 2013).

Salah satu tujuan Kementerian Pariwisata dan Ekonomi Kreatif meluncurkan wisata halal adalah menarik semakin banyak wisatawan asing, terutama Muslim. Terselip pula alasan lain yang mendasari diluncurkannya wisata jenis ini. Berdasarkan data Kementerian Pariwisata tahun 2013, dari sekitar 7 juta wisatawan dunia, 1,2 juta diantaranya adalah Muslim, yang tentunya mengharapkan wisata berbasis syariah. Dengan wisata halal, mereka akan mudah menemukan makanan halal dan tempat ibadah.

Namun, Indonesia meluncurkan wisata halal bukan semata untuk menarik wisatawan asing hingga meningkatkan jumlah kunjungannya per tahun. Keinginan dari turis domestik juga menjadi alasan karena menurut Kemenparekraf, semakin banyak wisatawan yang mengungkapkan kebutuhan mereka akan wisata halal.

Analisis SWOT adalah analisis kondisi internal maupun eksternal suatu organisasi yang selanjutnya akan digunakan sebagai dasar untuk merancang strategi dan program kerja. Analisis internal meliputi peniaian terhadap faktor kekuatan (Strength) dan kelemahan (Weakness). Sementara, analisis eksternal mencakup faktor peluang (Opportunity) dan tantangan (Threaths).

Keputusan strategis perusahaan perlu pertimbangan faktor internal yang mencakup kekuatan dan kelemahan maupun faktor eksternal yang mencakup peluang dan ancaman. Oleh karena itu perlu adanya pertimbangan- pertimbangan penting untuk analisis SWOT.

Dalam mengidentifikasi berbagai masalah yang timbul dalam perusahaan, maka sangat diperlukan penelitian yang sangat cermat sehingga mampu menemukan strategi yang sangat cepat dan tepat dalam mengatasi masalah yang timbul dalam perusahaan. Beberapa pertimbangan yang perlu diperhatikan dalam mengambil keputusan antara lain :

1. Kekuatan (Strenght)

Kekuatan adalah unsurunsur yang dapat diunggulkan oleh perusahaan tersebut seperti halnya keunggulan dalam produk yang dapat diandalkan, memiliki keterampilan dan berbeda dengan produk lain. sehingga dapat membuat lebih kuat dari para pesaingnya.

Kekuatan adalah sumber daya, keterampilan, atau keunggulan-keunggulan lain relatif terhadap pesaing dan kebutuhan pasar yang dilayani atau ingin dilayani oleh perusahaan. Kekuatan adalah kompetensi khusus yang memberikan keunggulan komparatif bagi perusahaan di pasar. Kekuatan terdapat pada sumber daya, keuangan, citra, kepemimpinan pasar, hubungan pembelipemasok, dan faktor-faktor lain.

2. Kelemahan (Weakness)

\section{Kelemahan} adalah kekurangan atau keterbatasan dalam hal sumber daya yang ada pada perusahaan baik itu keterampilan atau kemampuan yang menjadi penghalang bagi kinerja organisasi. Keterbatasan atau kekurangan dalam sumber daya, keterampilan dan kapabilitas yang secara serius menghambat kinerja efektif perusahaan. Fasilitas, sumber daya keuangan, kapabilitas manajemen, keterampilan pemasaran, dan citra 
merek dapat merupakan sumber kelemahan.

3. Peluang (opportunity)

Peluang adalah berbagai hal dan situasi yang menguntungkan bagi suatu perusahaan, serta kecenderungan-kecenderungan

yang merupakan salah satu sumber peluang.

4. Ancaman (Treats)

Ancaman adalah faktorfaktor lingkungan yang tidak menguntungkan dalam perusahaan jika tidak diatasi maka akan menjadi hambatan bagi perusahaan yang bersangkutan baik masa sekarang maupun yang akan datang. Ancaman merupakan pengganggu utama bagi posisi perusahaan. Masuknya pesaing baru, lambatnya pertumbuhan pasar, meningkatnya kekuatan tawar-menawar pembeli atau pemasok penting, perubahan tekhnologi, serta peraturan baru atau yang direvisi dapat menjadi ancaman bagi keberhasilan perusahaan.

Faktor kekuatan dan kelemahan terdapat dalam suatu perusahaan, sedang peluang dan ancaman merupakan faktor-faktor lingkungan yang dihadapi oleh perusahaan yang bersangkutan. Jika dapat dikatakan bahwa analisis SWOT merupakan instrumen yang ampuh dalam melakukan analisis strategi, keampuhan tersebut terletak pada kemampuan para penentu strategi perusahaan untuk memaksimalkan peranan faktor kekuatan dan pemanfaatan peluang sehingga berperan sebagai alat untuk meminimalisasi kelemahan yang terdapat dalam tubuh perusahaan dan menekan dampak ancaman yang timbul dan harus dihadapi.

\section{METODE}

Lokasi penelitian adalah di Sumatera Barat. Populasi adalah wilayah generalisasi yang terdiri dari: obyek/subyek yang mempunyai kualitas dan karakteristik tertentu yang ditetapkan oleh peneliti untuk dipelajari dan kemudian ditarik kesimpulannya (Sugiyono, 2014). Populasi dan sampel dalam penelitian ini adalah pemerintah daerah Sumatera Barat. Teknik analisa data menggunakan analisis SWOT (Strength, Weakness, Opportunity dan Threat). Analisis SWOT adalah sebuah metode perencanaan strategis yang digunakan untuk mengevaluasi Strengths, Weakness, Opportunities, dan Threats terlibat dalam suatu proyek atau dalam bisnis usaha. Hal ini melibatkan penentuan tujuan usaha bisnis atau proyek dan mengidentifikasi faktor-faktor internal dan eksternal yang baik dan menguntungkan untuk mencapai tujuan itu.

\section{HASIL}

Pengembangan wisata pada hakekatnya adalah suatu proses dalam rangka memperbaiki dan meningkatkan sesuatu yang telah ada. Pengembangan wisata dapat berupa kegiatan pembangunan, pemeliharaan dan pelestarian tanaman, sarana dan prasarana maupun fasilitas lainnya. Pengembangan wisata juga merupakan kegiatan pengembangan masyarakat dan wilayah yang didasarkan pada:

1. Memajukan tingkat hidup masyarakat sekaligus melestarikan identitas local

2. Meningkatkan tingkat pendapatan secara ekonomis serta pendistribusian merata kepada masyarakat

3. Berorientasi kepada pengembangan wisata berskala kecil dan menengah dengan daya serap tenaga kerja besar dan berorientasi kepada teknologi kooperatif

4. Memanfaatkan pariwisata seoptimal mungkin sebagai penyumbang tradisi negara.

Pengembangan wisata hanya dapat dikembangkan dengan menggunakan suatu strategi khusus. Strategi yang dapat 
digunakan adalah menggunakan metode analisis SWOT.

SWOT merupakan metode yang sangat lazim dan banyak digunakan dalam segala segi pengembangan bisnis termasuk pariwisata, strategi ini dilakukan dengan pengevaluasian terhadap kekuatan (Strengths), kelemahan (weakness), peluang (opportubities), dan ancaman (threats) dalam suatu proyek. SWOT merupakan sebuah alat analisis yang efektif dan efesien sebagai alat yang cepat dalam menemukan kemungkinan yang berkaitan dengan pengembangan awal progamprogam inovasi baru dalam kepariwisataan.

Penggunaan analisis SWOT dalam skenario pengembangan pariwisata adalah sebagai berikut:

1. Kekuatan (strengths) adalah mengetahui potensi wisata suatu wilayah, maka akan dapat bersaing dalam pasar dan mampu untuk pengembangan selanjutnya. Hal ini dapat digunakan untuk meraih peluang

2. Kelemahan (weakness) adalah segala sesuatu yang dapat merugikan sektor pariwisata. Pada umumnya kelemahankelemahan yang dapat diidentifikasi adalah kurangnya promosi, pelayanan yang tidak maksimal, kurang profesional dalam pengadaan pariwisata di lapangan, dan sulitnya lokasi dijangkau

3. Kesempatan (opportunities) adalah semua kesempatan yang ada sebagai akibat kebijakan pemerintah, peraturan yang berlaku atau kondisi perekonomian

4. Ancaman (threath) adalah berupa halhal yang dapat mendatangkan kerugian bagi pariwisata, seperti peraturan yang tidak memudahkan dalam berusaha, rusaknya lingkungan dan lainya.

Sumatera Barat saat ini menjadi salah satu destinasi wisata yang favorit. Pengembangan potensi wisata, promosi wisata serta pembangunan infrastruktur bidang pariwisata mampu menarik minat wisatawan baik dalam negeri maupun asing untuk berkunjung ke Sumatera Barat. Pariwisata di Sumatera Barat juga didukung potensi wisata yang beragam mulai wisata alam sampai budaya yang khas.

Konsep halal tourism menurut shakiry "The concept of sharia tourism is not limited to religious tourism, but it extend to all forms of tourist except those go against islamic values."

Untuk mengembangkan wisata syariah di Sumatera Barat maka diperlukan beberapa strategi khusus yang digunakan. Dalam hal ini Pemerintah Sumatera Barat melakukan promosi wisata dengan menggunakan media cetak serta pemanfaatan media luar dengan program pemasangan baliho, spanduk, poster dan billboard berisikan tentang jadwal-jadwal setiap event yang diselenggarakan.

Adapun event-event yang diselenggarakan dalam memgembangkan wisata syariah di Sumatera Barat adalah "Minangkabau Fashion Festival; Workshop Fashion/Mode Muslimah; Minangkabau Fashion Carnival; Pemilihan Duta Wisata Sumatera Barat; Islamic Fashion Festival; Sumarak Syawal; Festival Serambi Mekah; Sawahlunto Internasional Songket Carnaval; Payakumbuh Fashion Week; Pesta Budaya Tabuik; Potang Balimau; Karnaval 1 Muharram.

Berikut ini adalah langkah-langkah yang telah dilakukan dalam mengembangkan wisata syariah di Sumatera Barat :

1. Menjadikan Pariwisata sebagai sektor unggulan

2. Diimplementasikan melalui suatu Gerakan terpadu pengembangan kepariwisataan

3. Rapat-Rapat Koordinasi dengan Pemerintah Provinsi, Kabupaten/Kota dan Stakeholder terkait

4. Kesepakatan Pemerintah Provinsi, Kabupaten/Kota menjadikan 
Sumatera Barat sebagai Destinasi Wista Halal

5. Terpilihnya Sumbar sebagai Destinasi Halal Terbaik Nasional

6. Terpilihnya Sumbar sebagai Destinasi Kuliner Halal Terbaik Nasional

7. Terpilihnya Sumbar sebagai World's Best Halal Destination

8. Terpilihnya Sumbar sebagai World's Best Halal Culinary Destination

9. Sosialisasi Wisata Halal bagi Stackholder Pariwisata

10. Memberikan subsidi untuk pengurusan Sertifikasi Halal untuk industri (rumah makan/restoran)

11. Menyusun Ranperda Pariwisata Halal

Konsep wisata membuat wisatawan merasa "welcome" di destinasi wisata. Benchmark syariah di dalam masyarakat Aceh sendiri sulit diterima, karena hal tersebut berarti hukum syariah yang berlaku dan diterapkan sehingga masih ada ketakutan sendiri di masyarakat apalagi wisatawan. Label syariah bukan hanya sekedar kata tetapi maknanya sangat dalam.

Berdasarkan hasil penelitian, branding "halal" menjadi pilihan utama dalam branding pariwisata Sumatera Barat dibandingkan penggunaan branding "syariah", atau Islamic tourism. Jika branding syariah digunakan, dikhawatirkan akan menghilangkan konsep syar'i itu sendiri, yang ada malah hanya akan menghidupkan wisata konvensional saja. Untuk Sumatera Barat dapat menggunakan branding "Destinasi Pariwisata Berbasis Agama dan Budaya". Dengan demikian, konten halal yang harus dihidupkan mulai dari produk makanan hingga sarana/fasilitas pendukung pariwisata.

\section{SIMPULAN}

Berdasarkan hasil penelitian, maka stretegi pengembangan wisata syariah di Sumatera Barat adalah sebagai berikut :
1. Menjadikan Pariwisata sebagai sektor unggulan

2. Diimplementasikan melalui suatu Gerakan terpadu pengembangan kepariwisataan

3. Rapat-Rapat Koordinasi dengan Pemerintah Provinsi, Kabupaten/Kota dan Stakeholder terkait

4. Kesepakatan Pemerintah Provinsi, Kabupaten/Kota menjadikan Sumatera Barat sebagai Destinasi Wista Halal

5. Terpilihnya Sumbar sebagai Destinasi Halal Terbaik Nasional

6. Terpilihnya Sumbar sebagai Destinasi Kuliner Halal Terbaik Nasional

7. Terpilihnya Sumbar sebagai World's Best Halal Destination

8. Terpilihnya Sumbar sebagai World's Best Halal Culinary Destination

9. Sosialisasi Wisata Halal bagi Stackholder Pariwisata

10. Memberikan subsidi untuk pengurusan Sertifikasi Halal untuk industri (rumah makan/restoran)

11. Menyusun Ranperda Pariwisata Halal

\section{DAFTAR RUJUKAN}

Arif, Muhammad. 2018. Analisis Rekrutmen dan Penempatan Kerja terhadap Kinerja Karyawan pada Hotel Oase. Jurnal Al-Hikmah: Vol. 15 (1): 42-63.

Arif, M. (2019). The Effect of Managerial Competencies, Compesation and Career Planning Toward Employee Performance Through Job Satisfaction at PT. Bank BTPN Tbk Mikro Banking Division (MUR) Pekanbaru Branch. Journal of Management Info, 6(1), 1721.

Bungin, Burhan, Metodologi Penelitian Sosial, Surabaya : Airlangga University Press. 2004 
Fahad Salim Bahammam, Panduan Wisatawan Muslim. Jakarta : Pustaka Al-Kautsar. 2012

Hamzah, Maulana. M dan Yudiana, Yudi. Analisis Komparatif Potensi Industri Halal dalam Wisata Syariah dengan Konvensional. 2015

Global Muslim Travel Index (GMTI). 2016.

Kempar. Jumlah Kunjungan Wisatawan Mancanegara Menurut Pintu Masuk dan Kebangsaan. Jakarta : Kementerian Pariwisata. 2015

Kotler, Philip, dan Kevin L. Keller. Manajemen Pemasaran jilid 1. Alih Bahasa: Benyamin Molan. Edisi Ketiga Belas. Alih Bahasa : Bob Sabran. Jakarta: Erlangga. 2009

Kotler, Philip, dan Kevin L. Keller. Manajemen Pemasaran jilid 2. Alih Bahasa: Benyamin Molan. Edisi Ketiga Belas. Alih Bahasa : Bob Sabran. Jakarta: Erlangga. 2009

Kuncoro, Mudjarad, Metode Kuantitatif Teori dan Aplikasi untuk Bisnis dan Ekonomi. Yogjakarta : IPD STIM YKPN. 2007

Moleong, Lexy.J, Metodologi Penelitian Kualitatif, Bandung : Remaja Rosdakarya. 2005

Narbuko, Chalil, Abu Achmadi, Metodologi Penelitian, Jakarta : Penerbit Bumi Askara, 2004

Sarwono, J. Statistik Itu Mudah. Yogyakarta : CV Andi Offset. 2009

Setiadi. Perilaku Konsumen : Konsep dan Implikasi Untuk Strategi dan Penelitian Pemasaran. 2005

Sofyan, Riyanto. Prospek Bisnis Pariwisata Syariah. Jakarta : Republika. 2012

Sugiyono, Metode Penelitian Bisnis, Bandung : Alfabeta 2005

Suharso, Puguh, Model Analisis Kuantitatif. Jakarta : Indeks. 2010

Unggul Priyadi, Pariwisata SyariahProspek dan Perkembangan. UPP STIM YKPN. Yogyakarta. 2016 